DOI https://doi.org/10.30525/978-9934-26-074-2-31

\title{
КАНАДСЬКИЙ ДОСВІД ПРАВОВОГО РЕГУЛЮВАННЯ КРИПТОВАЛЮТИ ЯК ЦІННОГО ПАПЕРУ
}

\author{
Гнілуша С. I. \\ аспірант другого року навчання \\ за науковою спеціальністю «081-Право» \\ ВН3 «Університет економіки та права «КРОК» \\ м. Київ, Україна
}

Канада, як одна 3 технологічно провідних країн світу, на сьогоднішній день визнає криптовалюту та повністю легалізувала іiі. Однак, спочатку між державними органами проводилися дискусії щодо статусу даного виду активу. Так, у 2014 році Міністество фінансів Канади зазначило, що криптовалюта не буде визнана на державному рівні як платіжний засіб, по причині того, що вона є прямою загрозою канадській фінансовій системі та може порушити ії стабільність. В той же час, представник Банку Канади спростував цю думку та зазначив, що такі автономні системи, як Bitcoin не потрібно активно контролювати та регулювати.

Незважаючи на це, у квітні було проведено брифінг серед департаментів органів державної влади, де учасники прийняли рішення, що криптовалюта повинна бути визнаною в Канаді та повноцінно регулюватися, однак вона не може прирівнюватися до державної валюти країни.

У комплексному дослідженні В. В. Рисін, М. В. Рисін та І. В. Федюк стверджують [1], що Канаду потрібно віднести до списку країн, на рівні з Німеччиною, Нідерландами та іншими, які прирівняли криптовалюту до правового статусу національної валюти.

Однак, ця думка хибна, тому як криптовалюта як цифровий актив на національному рівні, відповідно до Закону про Банк Канади [2] не визнається як законна валюта на рівні канадського долару, а саме вказується: криптовалюта - це тип цифрової валюти, створеної за допомогою комп'ютерних алгоритмів, в той час цифрова валюта - це електронні гроші, які не доступні у вигляді купюр або монет.

Слід зазначити, що даний вид активу Агентством доходів Канади було охарактеризовано як товар та його використання можливе для оплати товарів або послуг. Такий вид операцій слід розглядати як бартертранзакцію. Так, згідно із визначенням у вищевказаному законодавчому акті цифрова валюта класифікується як цінний папір, а податкове 
законодавство Канади, включаючи Закон про податок на прибуток, застосовується до операцій з криптовалютою.

19 червня 2014 року генерал-губернатор Канади запропонував законодавчий акт Bill C-31 [3], що фактично вважається Законом про доходи від злочинів (відмивання грошей) та про фінансування тероризму. До даного акту було внесені поправки, що направлені на розгляд віртуальної валюти як «бізнесу з обслуговування грошей» для цілей положень про боротьбу з відмиванням грошей. Даний законодавчий акт направлений на регуляцію діяльності таких суб'єктів, як:

- компанії, що використовують криптовалюту для проведення операцій, включаючи токен Bitcoin;

- біржи, що здійснюють оперативну діяльність за допомогою криптовалюти;

- компанії, які проводять операції з розрахунком у криптовалюті на території Канади, однак фактично зареєстровані в іншій юрисдикції.

Таким чином, криптовалютні біржі в Канаді мають легальний статус та повинні проходити обов'язкову реєстрацію в системі FinTRAC [4] Центрі аналізу фінансових операцій та звітів. Якщо компанія не зареєстрована в зазначеній системі, то вона не має права відкривати рахунки в канадському банку. Серед першочергових функцій центру FinTRAC варто згадати саме сприяння виявлення, запобігання та стримування відмивання грошей та фінансування терористичної діяльності із забезпеченням захисту персональної інформації фізичних осіб.

У 2017 році Канадський регулятор цінних паперів (CSA) видав пам'ятку [5], в якій зазначаються правила випуску та критерії класифікації криптовалюти як цінного паперу. А отже, Канада $є$ однією з перших країн, що легалізувала та схвалила KYC-тa AML-політики для контролю надання послуг з куплі-продажу криптовалют, регулювання яких виконується згідно із законодавчими актами про цінні папери на рівні провінцій. Тобто, кожна така біржа повинна верифікувати користувача в обов'язковому порядку.

Важливо зазначити, всі операції з використанням криптовалюти в Канаді підлягають оподаткуванню. Приклад розрахування податку виду Capital Gains Tax було наведено в офіційному документі «Податкові питання, що стосуються Bitcoins» від 2013 року [6]. Так, відповідно до прикладу стосовно даного типу податку оподаткуванню підлягає тільки $50 \%$ від отриманого прибутку на приріст капіталу.

Задля допомоги канадцям у розумінні, як розраховувати податкові зобов'язання, Урядом Канади було випущено спеціальний Посібник для користувача криптовалют та податкових фахівців [7]. У зазначеному документі розглядують різні типи операцій, а саме:

- продаж чи подарування криптовалюти; 
Litecoin);

- торгівля або обмін криптовалюти (наприклад, обмін Bitcoin на

- конвертування криптовалюти в державну валюту;

- сплата послуг чи придбання товарів за допомогою криптовалюти.

Тобто, відповідно до цілей проведення транзакції розрізняють декілька видів податкового збору, відобразимо деталі в таблиці 1.

Таблиця 1

\begin{tabular}{|c|c|c|}
\hline Вид податку & Пояснення виду прибутку & Приклад операції \\
\hline $\begin{array}{l}\text { Corporation } \\
\text { Income Tax }\end{array}$ & $\begin{array}{c}\text { Податок на прибуток } \\
\text { корпорацій }\end{array}$ & $\begin{array}{c}\text { Здійснення комерційної } \\
\text { діяльності з використанням } \\
\text { криптовалюти: майнінг, } \\
\text { торгівля чи управління } \\
\text { діяльністю криптовалютної } \\
\text { біржі [6]. }\end{array}$ \\
\hline $\begin{array}{l}\text { Capital Gains } \\
\text { Tax }\end{array}$ & Податок на приріст капіталу & $\begin{array}{c}\text { Купівля, наприклад, } 1 \text { Віtсоіп } \\
\text { на початку його існування за } \\
\text { нижчою цінною та продаж } 1 \\
\text { Віtсоіп через час за вищою } \\
\text { ціною [8]. Також прикладом } \\
\text { можна вважати отримання } \\
\text { доходу від обміну одного } \\
\text { токену на інший вид токену та } \\
\text { через деякий час, коли перший } \\
\text { токен зростає - отримується } \\
\text { дохід. }\end{array}$ \\
\hline
\end{tabular}

Підсумовуючи вищезазначений досвід Канади у правовому регулюванні криптовалюти, варто зазначити, що більшість вітчизняних дослідників помиляються, коли стверджують, що криптовалюта в Канаді прирівнюється до національної валюти. Так, можливо, це через те, що операції з криптовалютою підпадають під оподаткування, однак у текстах законодавчих актів вказано, що криптовалюту прийнято вважати як цінний папір.

На мою думку, це було зроблено для того, аби зберегти стабільність канадського долару. Однак, у будь-якому випадку, Канада повноцінно регулює криптовалюту 32014 року, тому досвід організації цього процесу потрібно брати як за приклад для більшості країн світу, де контроль криптовалютних операцій, ще залишається вразливою точкою.

\section{Література:}

1. Рисін В. В., Рисін М.В., І. В. Федюк Правовий статус криптовалюти як фінансового інструменту. Ефективна економіка. 2018. № 11. C. 67-79. URL: http://www.economy.nayka.com.ua/pdf/11_2018/9.pdf (дата звернення: 15.04.2021). 
2. Digital currency. Government of Canada. URL: https://www.canada.ca/ en/financial-consumer-agency/services/payment/digital-currency.html (дата звернення: 15.04.2021).

3. BILL C-31. Parliament of Canada. URL: https://www.parl.ca/ DocumentViewer/en/41-2/bill/C-31/third-reading (дата звернення: 15.04.2021).

4. About FINTRAC. Financial Transactions and Reports Analysis Centre of Canada. URL: https://www.fintrac-canafe.gc.ca/intro-eng (дата звернення: 15.04.2021).

5. CSA Staff Notice 46-307 Cryptocurrency Offerings. Ontario Securities Commission. URL: https://www.osc.ca/sites/default/files/pdfs/irps/csa_ 20170824_cryptocurrency-offerings.pdf (дата звернення: 15.04.2021).

6. Transactions Involving Bitcoins. Canadian Tax Litigation. URL: http://www.canadiantaxlitigation.com/wp-content/uploads/2014/01/ 2013-0514701I7.txt?utm_(дата звернення: 15.04.2021).

7. Guide for cryptocurrency users and tax professionals. Government of Canada. URL: https://www.canada.ca/en/revenue-agency/programs/aboutcanada-revenue-agency-cra/compliance/digital-currency/cryptocurrencyguide.html (дата звернення: 15.04.2021).

8. Capital Gains 2020. Canada Revenue Agency. URL: https://www.canada.ca/content/dam/cra-arc/formspubs/pub/t4037/t403720e.pdf (дата звернення: 15.04.2021).

DOI https://doi.org/10.30525/978-9934-26-074-2-32

\title{
ВІДМІННОСТІ АДМІНІСТРАТИВНО-ПРАВОВОГО РЕГУЛЮВАННЯ ОБІГУ ЕЛЕКТРОННИХ КОШТІВ ТА КРИПТОВАЛЮТИ
}

\author{
Ковальчук О. В. \\ аспірантка другого року навчання кафедри \\ адміністративного права і проиесу \\ Національного педагогічного університету імені М. П. Драгоманова \\ м. Київ, Україна
}

На сьогоднішній день, технології розвиваються дуже швидко та держава не завжди вчасно реагує на появу нових технологічних рішень, в Україні така ситуація склалася із обігом криптовалют, адже об'єктивно ринок криптовалют існує, потенційне регулювання такого ринку може принести значні надходження до бюджету але на сьогоднішній 